https://doi.org/10.30910/turkjans.686733

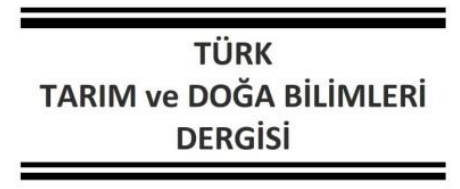

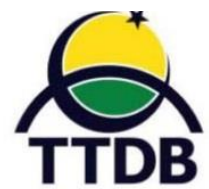

www.dergipark.gov.tr/turkjans

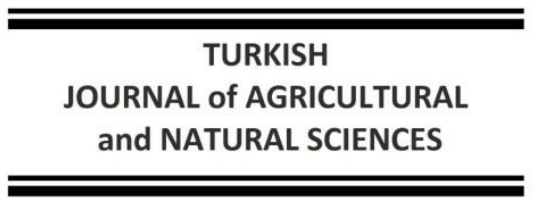

Araştırma Makalesi

\title{
Vakum Kurutucu ve Akışkan Yatak Kurutucu Kullanılarak Kurutulmuş Avokadoların Kuruma Kinetikleri ve Kalite Karakteristiklerinin Kıyaslanması
}

\author{
Sibel BÖLEK \\ Sağlık Bilimleri Üniversitesi, Sağlık Bilimleri Enstitüsü, Gıda Teknolojisi Anabilim Dalı \\ Sorumlu Yazar: sibel.bolek@sbu.edu.tr
}

\section{Geliş Tarihi: 08.02.2020 Düzeltme Geliş Tarihi: 27.08.2020 Kabul Tarihi: 08.10.2020}

\section{Öz}

Kurutma meyvelerdeki mikrobiyolojik ve kimyasal aktiviteyi sınırlandırmasının yanında, atıştırmalıklarla beslenme kültürünün giderek yaygınlaştığı günümüzde sağlıklı atıştırmalıkların elde edilmesine olanak sağlayan pratik bir yöntemdir. Kurutma işleminde gıdaların hem besleyici değerini hem de fiziksel ve duyusal özelliklerini iyi bir biçimde koruyan yöntemin seçilmesi son derece önemlidir. Bu çalışmada vakum kurutucu ve akışkan yatak kurutucu kullanılarak kurutulmuş avokadoların kalite karakteristiklerinin karşılaştırılması incelenmiştir. Başlangıç nem içeriği \%72.04 \pm 0.9 olan avokadolar nem içerikleri \%13.02 \pm 1 'e ulaşana kadar kurutulmuştur. Akışkan yatak kurutucuda kurutma işlemi $50^{\circ} \mathrm{C}, 60^{\circ} \mathrm{C}$ ve $70^{\circ} \mathrm{C}$ sıcaklıkta $1.5 \mathrm{~m} / \mathrm{s}$ hızla sırasıyla 8 saat, 7 saat ve 6 saatte, vakumla kurutma işlemi ise $10 \mathrm{Kpa}$ basınçta $50{ }^{\circ} \mathrm{C}, 60^{\circ} \mathrm{C}$ ve $70{ }^{\circ} \mathrm{C}$ sıcaklıklarında sırasıyla 10 saat, 9 saat ve 8 saatte tamamlanmıştır. Kurutulmuş avokadoların fiziksel, kimyasal ve duyusal özelliklerini kıyaslamak amacıyla renk, su aktivitesi, rehidrasyon kapasitesi, büzülme oranı, pH, antioksidan aktivite toplam fenolik madde ölçümleri ve duyusal analiz testleri gerçekleştirilmiştir. Çalışmanın sonucunda vakumla kurutma işleminin avokadoların fiziksel ve kimyasal özelliklerinin yanı sıra duyusal özelliklerini daha iyi koruyan bir yöntem olduğu ortaya çıkarılmıştır.

Anahtar kelimeler: Avokado, kurutma, akışkan yatak, vakum

\section{Comparison of Drying Kinetics and Quality Characteristics of Avocados Dried Using Vacuum Dryer and Fluidized Bed Dryer}

\begin{abstract}
Besides limiting microbiological and chemical activity in fruits, drying is a practical method that provides healthy snacks nowadays, when culture of nutrition with snacks is increasingly common. It is very important to choose a method that preserves both nutritional values and physical and sensory properties of foods in the drying process. In this study, the comparison of quality characteristics of dried avocados using vacuum dryer and fluidized bed dryer was investigated. Avocados with initial moisture content of $72 \pm 09 \%$ were dried until their moisture content reached $13 \pm 1 \%$. The drying process in the fluidized bed dryer was completed at $50{ }^{\circ} \mathrm{C}$, $60{ }^{\circ} \mathrm{C}$ and $70^{\circ} \mathrm{C}$ with $1.5 \mathrm{~m} / \mathrm{s}$ speed in 8 hours, 7 hours and 6 hours respectively, while the vacuum drying process was completed at $10 \mathrm{Kpa}$ pressure at $50{ }^{\circ} \mathrm{C}, 60^{\circ} \mathrm{C}$ and $70{ }^{\circ} \mathrm{C}$ temperatures in 10 hours, 9 hours and 8 hours respectively. In order to compare the physical, chemical and sensory properties of dried avocados, color, water activity, rehydration capacity, shrinkage rate, $\mathrm{pH}$, antioxidant activity, total phenolic content measurements and sensory analysis tests were conducted. $(p<0.05)$. In the result of this study, it has been revealed that vacuum drying is a method that better preserves the physical and chemical properties of avocados as well as their sensory properties.
\end{abstract}

Key words: Avocado, drying, fluidized bed, vacuum 


\section{Giriş}

Meyvelerin kurutularak muhafazası hem gıdanın mevsimi dışında tüketilmesine olanak sağlanması, hem de meyvelerin taşıma ve depolama maliyetlerinin azaltılması açısından son derece önemlidir. Diğer taraftan, günümüzde atıştırmalıklarla beslenme kültürünün giderek yaygınlaştığı dönemde sağlıklı atıştırmalıkların elde edilmesine de olanak sağlamaktadır. Son üründeki kalite kayıplarının en aza indirilmesi için gıdaların uygun şekilde kurutulması gerekmektedir. İnsanın doğadan öğrendiği ilk kurutma yöntemi olan güneşte kurutmadan başlayan süreçte kurutma için pek çok yöntem geliştirilmiştir. Güneşte kurutma yöntemi enerji ve ekipman maliyeti gerektirmemesi gibi avantajlara sahip olmasına rağmen gıdaların uzun süre dış etkenlere karşı açık bir ortamda bekletilmesinin kurutulan üründe kalite kayıplarına neden olması kurutma için yeni yöntem ve cihazlar geliştirmeyi gerektirmiştir. Gıdaların kurutulmasında sıcak hava (Michalczyk ve ark., 2009; Opalić ve ark., 2009), dondurarak kurutma (Shishehgarha, 2002; Shofian ve ark., 2011), vakum kurutma (Krokida ve ark., 2001; Gabas ve ark., 2007), ozmotik kurutma (Teles ve ark., 2006; Mayor ve ark., 2007), ISI pompalı (Artnaseaw ve ark., 2010; Shi ve ark., 2013) ve elektrohidrodinamik kurutma (Dinani ve ark., 2015; Martynenko ve Zheng, 2016) gibi farklı yöntemlerin kullanıldığı pek çok çalışma mevcuttur. Gıdaların kalitesini en iyi koruyan yöntemlerden bir olan dondurarak kurutma yüksek yatırım ve işletme maliyeti gerektirmekte dolayısıyla elde edilen son ürünün satış fiyatında yükselmeye neden olmaktadır. $30{ }^{\circ} \mathrm{C}, 50{ }^{\circ} \mathrm{C}$ gibi düşük sıcaklıklarda gerçekleşen ozmotik kurutma işlemi gıdanın oksijene maruz kalmadan kalitesinde minimum kayıpla suyun uzaklaştırılmasını sağlayan etkili metotlardan biridir (Feng ve ark., 2019) ancak, üründeki bazı suda çözünür bileşenlerin ozmotik çözeltiye geçmesi ve ürün nem içeriğinde yeterli mikrobiyal güvenliğin sağlanamaması nedeniyle çoğunlukla dondurma, pastörizasyon, kurutma ve konserveleme gibi işlemlerden önce bir ön işlem olarak kullanılmaktadır. Bununla birlikte söz konusu işlemde kuruma süresi oldukça uzundur. Isı pompalı kurutucular enerji tasarrufu ve ürün kalite özellikleri bakımından büyük avantajlar sağlamasına rağmen sistemin ilk kuruluş maliyetlerinin çok yüksek olması ve birçok ISI pompası sisteminde ozon tabakasına zarar verdiği bilimsel araştırmalarla ortaya konulmuş olan kloroflorokarbon kullanılması ayrıca sürekli bakım gerektirmesi gibi sınırlamaları bulunmaktadır (Gürlek ve ark., 2015). Elektrohidrodinamik kurutma düşük işletme maliyetinin yanında gıdaların renk, tekstür ve besin değeri gibi karakteristiklerini koruması gibi avantajlara sahiptir. Ancak kurutmanın ilk safhasında oldukça etkili olup kurutma işlemi ilerledikçe yöntemin etkinliği azalmaktadır bu nedenle de sadece diğer kurutma teknikleri ile kombine olarak kullanılması mümkün olmaktadır (Wong ve Lai, 2004). Son yıllarda hızlı ve pratik bir yöntem olan mikrodalga kurutma gıda endüstrisi için alternatif bir yöntem olarak ivme kazanmıştır. İşlem süresinin kısa oluşu, enerji tasarrufu sağlaması, gıdaların renk tekstür gibi duyusal özelliklerini koruması sistemin önemli avantajlarıdır. Ancak kuruluş masraflarının yüksek oluşu ve kurutma işleminde yeterli homojenlik sağlanamaması sistemin sınırlamalarıdır. Yüksek sıcaklık ve uzun süre ile karakterize olan sıcak hava ile kurutma yöntemi kuruluş ve işletme maliyetleri düşük olmakla birlikte genellikle üründe ISI hasarına neden olarak ürünlerin doku, renk, lezzet ve besin değerini olumsuz etkilemektedir (Asami ve ark., 2003; Chang ve ark., 2006). Akışkan yatak kurutucu ile kurutma işlemi ise homojen bir kurutma sağlayarak, üründe kurutma esnasında ısınan yüzeylerle temastan kaynaklı yanmayı önlemesi gibi önemli avantajlara sahiptir (Bolek ve Ozdemir, 2017). Diğer taraftan vakum kurutucularda suyun uzaklaştırılması esnasında ortamda hava bulunmadığı için oksidasyon önlenmekte renk, tekstür ve aroma da iyi bir şekilde korunmaktadır (Yongsawatdigul ve Gunasekaran, 1996).

Avokado besleyici değeri son derece yüksek olmasının yanında yüksek antioksidan aktiviteye sahip bir meyve (Rodríguez-Carpena ve ark., 2011) olmasına rağmen, literatürde avokadonun kurutulması ile ilgili çok az sayıda çalışma mevcuttur. Bu çalışmalar genellikle kurutma sırasındaki kütle transferini belirlemeye yönelik olup, kurutma işleminin avokadonun kalite karakteristikleri üzerine etkisini belirlemeyi amaçlamamıştır. Ayrıca söz konusu çalışmalarda akışkan yatak kurutucu ve vakumlu kurutucunun ürünün kalite karakteristikleri ve duyusal özellikleri üzerine etkileri de kıyaslanmamıştır. Bu çalışmanın amacı yüksek besin değerine sahip ve sağlık açısından son derece yararlı bileşenler içeren (Chartzoulakis ve ark., 2002) avokadoların kalite karakteristiklerinin iyi bir şekilde korunarak kurutulmasını sağlamaktır. Bunun için de vakum kurutma ve akışkan yatak kurutma işlemlerinin avokadoların fiziksel, kimyasal ve duyusal özellikleri üzerine etkileri kıyaslanarak daha iyi sonucu veren yöntemin belirlenmesi hedeflenmiştir. 


\section{Materyal ve Metot}

Çalışmada kurutma işlemi için Mersin'in Çeşmeli ilçesinde yetiştirilen Hass türü avokadolar (Persea americana Mill) kullanılmıştır. Kullanılan avokadoların fiziksel özellikleri Çizelge 1'de verilmiştir. Her bir meyvenin ağırlığı 0,01 g'a duyarlı hassas terazi ile ölçülmüştür. Meyvelerin boyu ve eni $0,01 \mathrm{~mm}$ hassasiyete sahip kumpas ile ölçülmüştür. Meyve eti oranı, tüm meyve ağırlığından, kabuk ve çekirdek ağırlığı (posa) çıkarılarak elde edilen değerin tüm meyve ağırlığına bölünmesiyle bulunmuştur. Meyve çekirdeği oranı, çekirdek ağırlığı meyve ağırlığına bölünerek elde edilmiştir.

Çizelge 1. Avokadoların Fiziksel Özellikleri

\begin{tabular}{|c|c|c|c|c|}
\hline $\begin{array}{l}\text { Meyve ağırlığı } \\
\text { (g) }\end{array}$ & $\begin{array}{l}\text { Meyve boyu } \\
(\mathrm{mm})\end{array}$ & Meyve eni (mm) & $\begin{array}{l}\text { Meyve eti } \\
\text { oranı (\%) }\end{array}$ & Meyve çekirdeği oranı (\%) \\
\hline $150,12 \pm 2,14$ & $95,06 \pm 1,01$ & $55,86 \pm 0,92$ & $73,93 \pm 1,04$ & $12,35 \pm 0,05$ \\
\hline
\end{tabular}

*Tüm değerler 3 tekerrürün ortalamasıdır.

Kabukları bıçakla manuel olarak soyulan avokadolar $3 \mathrm{~cm}$ kalınlığında dilimlenmiştir. Başlangıç nem içeriği \%72 \pm 09 olan avokadolar nem içerikleri \%13 \pm 1 'e ulaşana kadar akışkan yatak kurutucu ve vakumlu etüv kullanılarak kurutulmuştur. Akışkan yatak kurutucuda kurutma işlemi laboratuvar tipi bir akışkan yatak kurutucu (Retsch-TG 100 , Germany) kullanılarak $50^{\circ} \mathrm{C}, 60^{\circ} \mathrm{C}$ ve $70^{\circ} \mathrm{C}$ sıcaklıklarında sırasıyla 8 saat, 7 saat ve 6 saat boyunca $1,5 \mathrm{~m} / \mathrm{s}$ hava hızında gerçekleştirilmiştir. Vakumla kurutma işlemi bir vakumlu etüv (Binder-VD 23) kullanılarak $10 \mathrm{Kpa}$ basınçta $50{ }^{\circ} \mathrm{C}, 60{ }^{\circ} \mathrm{C}$ ve $70{ }^{\circ} \mathrm{C}$ sıcaklıklarında sırasıyla 10 saat, 9 saat ve 8 saat boyunca gerçekleştirilmiştir. Kurutma işlemi süresince ağırlık kaybı izlenerek tüm örneklerin belirlenen son nem düzeyine gelmeleri sağlanmıştır.

Kurutulmuş avokadoların fiziksel, kimyasal ve duyusal özelliklerini kıyaslamak amacıyla renk ölçümü, su aktivitesi tayini, rehidrasyon kapasitesi tayini, büzülme oranı tayini, $\mathrm{pH}$ tayini, antioksidan aktivite tayini, toplam fenolik madde tayini ve duyusal analiz testleri gerçekleştirilmiştir.

\section{Renk Analizi}

Örneklerin yüzey renklerini ölçmek için Minolta DP-301 (Osaka, Japonya) model bir kolorimetre kullanılmıştır. Renk tespitinde Hunter renk parametreleri ( $L^{*}$ (parlaklık), a*(kırmızılık) ve $b^{*}$ (sarılık) değerleri) göz önünde bulundurulmuştur. $L^{*}=93.3, a^{*}=0.3162$ ve $b^{*}=$ 0.3321 (beyaz plaka) değerleri kalibrasyon için referans olarak kullanılmıştır.

\section{Nem Tayini}

Avokadoların nem içeriği AOAC (2005)'te belirtilen yönteme göre gravimetrik olarak belirlenmiştir. Örneklerden $2 \mathrm{~g}$ alınarak etüvde (Ecocell 55, MMM Medcenter Einrichtungen $\mathrm{GmbH}$, München, Germany) $100{ }^{\circ} \mathrm{C}^{\prime}$ de sabit tartıma getirilmiştir.

\section{Rehidrasyon Kapasitesi}

The total flavonoid contents of C. barbata samples were determined based on the method proposed by Quettier- Deleu et al. (2000). The results were stated as milligram per gram extract.

\section{Büzülme Oran}

Kurutulmuş avokadoların büzülme oranlarını tayin etmek için örneklerin kuruma sonrası hacimleri kuruma öncesi hacimlerine bölünerek hesaplanmıştır (Yıldız ve Gökayaz, 2019). pH Tayini

$\mathrm{pH}$ değeri, pH-metre ile (SevenEasy S20-K, Mettler Toledo) Cemeroğlu (2010) tarafından önerilen yönteme göre belirlenmiştir. Bu amaçla kurutulmuş örneklerden yaklaşık $10 \mathrm{~g}$ örnek alınarak $90 \mathrm{~mL}$ saf su içinde 1 gün süreyle $+4{ }^{\circ} \mathrm{C}^{\prime}$ de rehidrasyona bırakılmıştır. $\mathrm{Bu}$ karışım, daha sonra havanda dövülüp homojen hale getirildikten sonra, kaba filtre kağıdından filtre edilmiştir. Elde edilen filtratın $\mathrm{pH}$ değeri $\mathrm{pH}$ metre ile doğrudan ölçülerek saptanmıştır (Bchir ve ark., 2012).

\section{Antioksidan Aktivite Tayini}

Analiz için farklı konsantrasyonlarda örnek ekstraktları $(10-40 \mu \mathrm{g} / \mathrm{ml})$ hazırlanarak etanol ile 2 ml'ye seyreltilmiştir. Üzerine etanol ile hazırlanan DPPH çözeltisinden (1 mM) $500 \mu$ l ilave edilmiştir. Daha sonra vorteks ile karıştırılıp, karanlıkta 30 ${ }^{\circ} \mathrm{C}^{\prime}$ de $30 \mathrm{dk}$ boyunca karanlık bir ortamda inkübe edilmiştir. Kör çözelti olarak etanol kullanılmıştır. Absorbans $517 \mathrm{~nm}$ 'de kör çözeltiye karşı ölçülmüştür. Absorbanstaki azalma DPPH serbest radikal süpürme aktivitesini göstermiştir. Elde edilen absorbans değerlerinden \% inhibisyon değerleri hesaplanmıştır (Ye ve ark., 2000).

$\%$ inhibisyon $=[($ ADPPH-Aekstrakt $) /$ ADPPH $] \times 100$

ADPPH: DPPH şahit örneğin absorbans değeri Aekstrakt: Örnek ekstraktın absorbans değeri Inhibisyon değerleri örnek hacimlerine karşı grafiğe aktarılıp linear regrasyon analizi uygulanarak örneklere ait eşitlikler belirlenmiştir. 


\section{Toplam Fenolik Madde Tayini}

Kurutulmuş avokadoların toplam fenolik madde içeriği Cemeroğlu (2010) tarafından önerilen yöntemde küçük modifikasyonlar yapılarak belirlenmiştir. $5 \mathrm{~g}$ örnek alınıp $50 \mathrm{ml}$ \%80'lik metil alkol içerisinde havanda $5 \mathrm{dk}$ dövülerek homojenize edilmiştir. Homojenat bir behere alınıp $5 \mathrm{dk}$ süreyle kaynatılmıştır. Ekstrakt Whatman 4 filtre kağıdından filtre edilmiştir. Beherdeki kalıntı üzerine tekrar $50 \mathrm{ml} \% 80^{\prime}$ lik metil alkol eklenip $10 \mathrm{dk}$ daha kaynatılmıştır. Her iki ekstrakt $100 \mathrm{ml}$ lik balon jojede birleştirilip soğumaya bırakılmıştır. Soğuduktan sonra balon joje çizgisine kadar saf suyla tamamlanmıştır. Ekstrakttan 50 ml'lik balon joje içerisine $5 \mathrm{ml}$ alınıp üzerine $5 \mathrm{ml}$ saf su ilave edilmiştir. Daha sonra üzerine $0,5 \mathrm{ml}$ Folin-ciocalteu ayracı eklenip balon iyice çalkalanmıştır. $3 \mathrm{dk}$ beklendikten sonra üzerine $1 \mathrm{ml} \% 36^{\prime} l ı k$ sodyum karbonat çözelitisi eklenen balon, saf su ile tekrar çizgisine kadar tamamlandıktan sonra tekrar iyice çalkalanıp karanlık bir ortamda 1 saat bekletilmiştir. Bekleme süresi sonunda spektrofotometrede $725 \mathrm{~nm}$ dalga boyunda okuma yapılmıştır.

Stok çözeltinin hazırlanması: $0.1 \mathrm{gr}$ gallik asit $100 \mathrm{ml}$ metanolle seyreltilmiştir.

Standart çözeltilerin hazırlanması: $0,0.4$, $0.8,1.2,1.6,2 \mathrm{mg} / \mathrm{ml}$ konsantrasyonda çözeltiler gerekli seyreltmeler yapılarak hazırlanmıştır. Her bir örnek için okunan absorbans değerlerine karşı konsantrasyon miktarı kalibrasyon grafiğinden belirlenmiş, sonuçlar seyreltme katsayıları dikkate alınarak $\mathrm{mg} / 100 \mathrm{~g}$ olarak gallik asit cinsinden hesaplanmıştır.

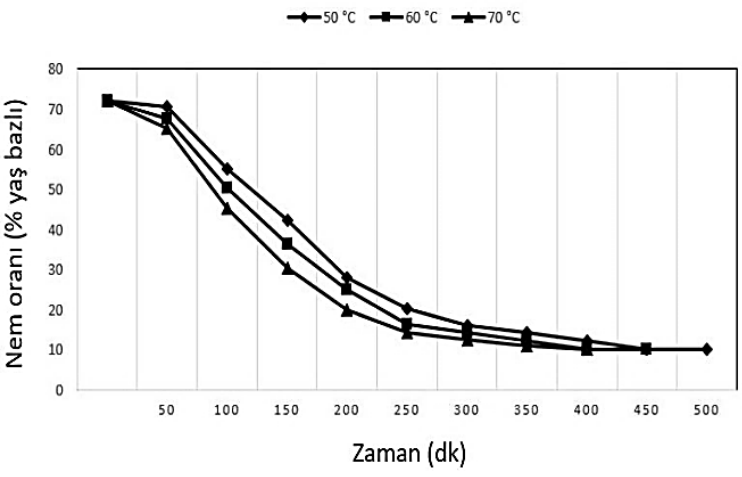

Grafik 1. Akışkan yatak kurutma işleminde nem içeriğinin zamanla değişimi

\section{Kurutma işleminin renk değerleri üzerine etkisi}

Renk tüketici tarafından ilk algılanan özelliktir ve tüketicinin gıdayı kabul ya da ret kararını doğrudan etkilemektedir. Kurutulmuş avokado örneklerinin renk değerleri Çizelge 2'de

\section{Duyusal Analiz}

Kurutulmuş avokadoların görünüş, doku, lezzet ve genel izlenim bakımından kıyaslanmasıyla duyusal panel tarafından en beğenilen örneği bulmak amacıyla 5 puanlı hedonik skala $(1=$ Hiç beğenmedim, 2 = Beğenmedim, $3=\mathrm{Ne}$ beğendim ne beğenmedim, 4 = Beğendim, 5 = Çok beğendim) kullanılmıştır (Meilgaard ve ark., 2016). Duyusal panelde yaşları 20-50 arasında değişen yarı eğitimli 60 panelist kullanılmıştır. Analiz ISO 8586 (2012) normlarına uygun olarak gerçekleştirilmiştir. Avokado dilimleri rastgele 3 haneli rakamlarla kodlanmış porselen tabaklarda panelistlere sunulmuştur. Analiz 3 tekerrürlü olarak uygulanmıştır. Analiz ortamı beyaz floresan ampul kullanılarak aydınlatılmıştır. Her uygulamada panelistlere 6 farklı örnek sunulmuştur. Örnek sunumları arasında ağızda oluşan kalıntı tadı gidermek için su kullanılmıştır.

\section{istatistiksel Analiz}

Tüm kurutma uygulamaları üç tekerrürlü yapılmış ve elde edilen kurutulmuş örneklerin analizleri de 3 paralel olarak gerçekleştirilmiştir. Analizlerden elde edilen veriler SPSS (version 15 for windows, SPSS, Inc., Chicago, IL, USA) istatistiksel paket programı kullanılarak "Varyans analizi" ve "Duncan çoklu karıştırma testi"nde 0,05 önem düzeyine göre analiz edilmiştir.

$\mathrm{S}^{(2)}=$ Nassar ve.

\section{Bulgular ve Tartışma \\ Nem içeriği}

Grafik 1 ve Grafik 2'de akışkan yatak ve vakum kurutma işleminde avokadoların nem içeriğinin zamanla değişimi gösterilmiştir.

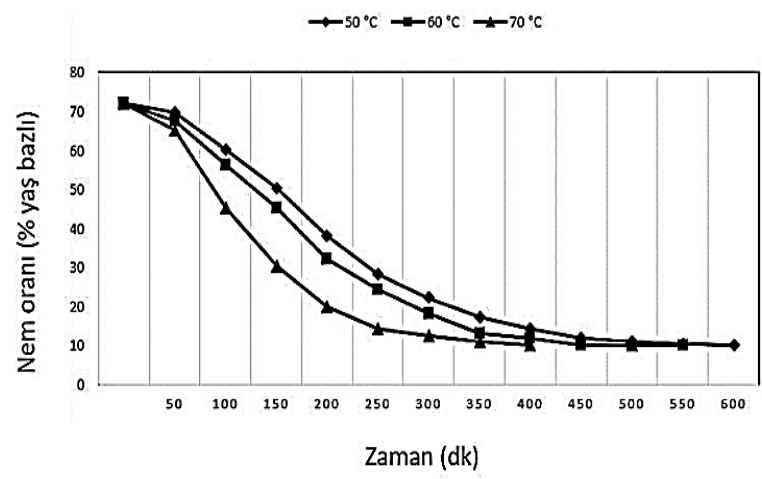

Grafik 2. Vakum kurutma işleminde nem içeriğinin zamanla değişimi

gösterilmiştir. Akışkan yatak kurutucuda kurutulan örneklerin $L^{*}$ ve $b^{*}$ değerleri vakumlu etüvde kurutulmuş örneklere göre daha düşük bulunmuştur. Bu sonuç akışkan yatak kurutucuda enzimatik ve enzimatik olmayan esmerleşme 
reaksiyonlarının daha yoğun gerçekleşmesiyle açıklanabilir. Diğer taraftan kurutma işlemi süresince örneklerin $L^{*}$ ve $b^{*}$ değerleri azalırken $a^{*}$ değerlerinde artış gözlenmiştir. Kurutma sıcaklığı arttıkça $L^{*}$ ve $b^{*}$ değerlerinde daha fazla düşüş, a* değerlerinde ise daha fazla artış gerçeklemiştir. Avokadoların sıcak hava ile kurutulması esnasındaki kütle transferinin matematiksel olarak modellendiği çalışmada da benzer şekilde kurutma işlemi ilerledikçe $L^{*}$ ve $b^{*}$ değerleri azalırken $a^{*}$ değerlerinde artış görülmüştür (opali ve Katsioti, 2000). Bu çalışmaya benzer olarak sıcak hava ve vakumla kurutmanın karalahanaların renk değerleri üzerine etkisinin araştırıldığı bir çalışmada kullanılan karalahanalarda vakumlu kurutucu ile kurutulmuş örneklerin $L^{*}$ ve $b *$ değerlerinde daha az düşüş gerçekleşmiştir (Alibas, 2009).

Çizelge 2. Kurutulmuş avokado dilimlerinin $L^{*}, a^{*}, b^{*}$ değerleri

\begin{tabular}{|c|c|c|c|c|}
\hline \multirow{2}{*}{\multicolumn{2}{|c|}{$\begin{array}{l}\text { Kurutma sıcaklığı }\left({ }^{\circ} \mathrm{C}\right) / \\
\text { Zaman (saat) }\end{array}$}} & \multicolumn{2}{|c|}{ Renk değerleri } & \multirow[b]{2}{*}{$b^{*}$} \\
\hline & & $L^{*}$ & $a^{*}$ & \\
\hline $50^{\circ} \mathrm{C}, 8$ saat & & $45.21^{b}$ & $0.22^{b}$ & $18.62^{b}$ \\
\hline $60^{\circ} \mathrm{C}, 7$ saat & - Akışkan yatak & $37.16^{c}$ & $0.93^{a}$ & $16.02^{c}$ \\
\hline $70{ }^{\circ} \mathrm{C}, 6$ saat & kurutucu & $30.08^{d}$ & $1.12^{\mathrm{a}}$ & $15.12^{\mathrm{d}}$ \\
\hline $50^{\circ} \mathrm{C}, 10$ saat & & $48.28^{a}$ & $-1.36^{c}$ & $20.42^{a}$ \\
\hline $60^{\circ} \mathrm{C}, 9$ saat & Vakumlu & $43.16^{b}$ & $0.65^{a}$ & $18.92^{\mathrm{b}}$ \\
\hline $70{ }^{\circ} \mathrm{C}$, 8 saat & kurutucu & $38.08^{c}$ & $1.09^{a}$ & $16.21^{\mathrm{c}}$ \\
\hline
\end{tabular}

*Aynı satırda farklı harfleri taşıyan ortalamalar arası fark önemlidir $(p<0.05)$. Tüm değerler 3 tekerrürün ortalamasıdır.

\section{Kurutma işleminin su aktivitesi, rehidrasyon yeteneği ve büzülme oranı üzerine etkisi}

Su Aktivitesi gıdada bulunan serbest su miktarının bir ölçüsüdür. Özellikle mikrobiyolojik faaliyetler için gıdalardaki suyun kullanılabilme durumu belirlemektedir. Avokadoların kurutma sonrası su aktivitesi değerleri 0.48-0.49 arasında bulunmuştur (Çizelge 3). Akışkan yatak kurutucu ile kurutulmuş ve vakumlu kurutucu ile kurutulmuş avokadoların su aktivitesi değerleri arasında istatistiksel olarak önemli bir fark bulunamamıştır ( $p>0.05$ ). Su aktivitesi değerleri 0,6'nın altında olan gıdalar mikroorganizmaların gelişimi için elverişsiz olduğundan uygulanan kurutma işleminin kurutulmuş avokadoların bozulmadan muhafaza edilecek düzeylere ulaştırmada yeterli olduğu sonucuna ulaşılmıştır.

Rehidrasyon kapasitesi kurutma yöntemi ile doğrudan ilişkili bir özelliktir (Litvin ve ark., 1998). Kurutulmuş bir ürünün suda bekletilmesi sırasında, kurutulmadan önceki miktarda içerdiği suyu bünyesine alarak eski haline dönmesi ürünün yapısının kurutma esnasında hiç zarar görmediği anlamına gelmektedir (Cemeroğlu, 2010). Kurutulmuş avokadoların rehidrasyon kapasiteleri Çizelge 3'te gösterilmiştir. Vakumlu kurutucu ile kurutulmuş örneklerin rehidrasyon kapasiteleri akışkan yatak kurutucuda kurutulmuş örneklerin rehidrasyon kapasitesinden yüksek bulunmuştur $(p<0.05)$. Bu sonuç vakumla kurutma işleminin gıdaların yapısını akışkan yatak kurutmaya göre daha iyi koruduğunu ortaya koymuştur. Kurutma sıcaklığı arttıkça hem akışkan yatak kurutucuda kurutulmuş hem de vakumlu kurutucuda kurutulmuş örneklerin rehidrasyon kapasitelerinde düşüş görülmüştür. Balzarini ve ark. (2018) hindiba köklerini sıcak hava ve vakumlu kurutucu ile kurutmuş ve çalışmanın sonucunda benzer şekilde vakumla kurutulmuş örneklerin daha yüksek rehidrasyon kapasitesine sahip olduğunu ortaya koymuştur.

Büzülme kurutulmuş ürünler için olumsuz bir özellik olup büzülme oranının 1'e yakın olması gıdanın yapısının zarar görmeden, uygun şekilde kurutulduğunun bir ifadesidir (Cemeroğlu 2010). Kurutulmuş avokadoların büzülme oranları Çizelge 3'te gösterilmiştir. Rehidrasyon kapasitesi değerlerine paralel olarak vakumla kurutulmuş avokadoların büzülme oranları 1'e daha yakın bulunmuştur $(p<0.05)$.

Kurutma işleminin $\mathrm{pH}$ değeri, antioksidan aktivite ve toplam fenolik madde üzerine etkisi

Kurutma işlemi ilerledikçe avokadoların pH değerlerinde düşüş gözlenmiştir (Çizelge 4). Vakumlu kurutucu ile kurutulmuş avokadoların pH değerleri akışkan yatak kurutucu ile kurutulmuş avokadoların $\mathrm{pH}$ değerlerinden daha yüksek bulunmuştur $(p<0.05)$. İncirlerin hava akımı ile kurutulduğu çalışmada kurutma işlemi ilerledikçe 
incirlerin $\mathrm{pH}$ değerlerinde istatistiksel olarak önemli ölçüde düşüş gözlemlenmiş ve bu sonuç meyvelerin içerdiği karbonhidratların kurutma esnasında asitlere parçalanması ile açıklanmıştır (Piga ve ark., 2004).

Çizelge 3. Kurutulmuş avokado dilimlerinin su aktivitesi, rehidrasyon yeteneği büzülme değerleri

$\begin{array}{cccc}\text { Kurutma sıcaklığı }\left({ }^{\circ} \mathrm{C}\right) / & \text { Su aktivitesi } & \text { Rehidrasyon } & \text { Büzülme } \\ \text { Zaman (saat) } & \text { (gsu/gkuru madde) } & \text { kapasitesi } & \text { oranı }\end{array}$

$50{ }^{\circ} \mathrm{C}, 8$ saat
$60{ }^{\circ} \mathrm{C}, 7$ saat
$70{ }^{\circ} \mathrm{C}, 6$ saat

*Aynı satırda farklı harfleri taşıyan ortalamalar arası fark önemlidir $(p<0.05)$. Tüm değerler 3 tekerrürün ortalamasıdır.

Kurutma işlemi ilerledikçe avokadoların antioksidan aktivite ve toplam fenolik madde içeriklerinde belli bir dereceye kadar artış sonrasında da düşüş gözlemlenmiştir (Çizelge 4). $\mathrm{Bu}$ sonuç kurutma esnasında Maillard reaksiyon ürünleri gibi yeni fenolik ve antioksidatif maddelerin oluşması ve kurutma işlemi ilerledikçe bu oluşmuş maddelerin parçalanması ile açıklanabilir. Astudillo-Ordóñez ve Rodríguez
(2018) Hass türü avokadoların fizikokimyasal özelliklerini inceledikleri çalışmada toplam fenolik madde ve antioksidan içerikleri için benzer sonuçlar elde etmişlerdir. Vakumla kurutulmuş avokadoların antioksidan aktivitesi akışkan yatakla kurutulmuş avokadolardan daha yüksek bulunmuştur. Bu durumun vakumla kurutmada ortamda oksijenin olmamasından kaynaklandığı düşünülmektedir ortamda oksijenin olmamasından kaynaklandığı düşünülmektedir.

Çizelge 4. Kurutulmuş avokado dilimlerinin $\mathrm{pH}$, antioksidan aktivite ve toplam fenolik madde değerleri

\begin{tabular}{|c|c|c|c|c|}
\hline \multicolumn{2}{|c|}{$\begin{array}{l}\text { Kurutma sıcaklığı }\left({ }^{\circ} \mathrm{C}\right) / \\
\text { Zaman (saat) }\end{array}$} & \multirow{2}{*}{$\begin{array}{l}\mathrm{pH} \\
5.86^{\mathrm{b}}\end{array}$} & \multirow{2}{*}{$\begin{array}{l}\text { Antioksidan aktivite } \\
\% \text { Inhibisyon } \\
\text { (DPPH) } \\
29.25^{\mathrm{f}}\end{array}$} & \multirow{2}{*}{$\begin{array}{c}\text { Toplam fenolik maddde } \\
\text { (mg gallik asit/ } \\
100 \text { g ekstrakt) }\end{array}$} \\
\hline $50^{\circ} \mathrm{C}, 8$ saat & Akışkan & & & \\
\hline $60^{\circ} \mathrm{C}, 7$ saat & yatak & $5.53^{b}$ & $35.30^{d}$ & $77.44^{d}$ \\
\hline $70^{\circ} \mathrm{C}, 6$ saat & kurutucu & $5.47^{b}$ & $33.14^{\mathrm{e}}$ & $76.21^{\mathrm{e}}$ \\
\hline $50^{\circ} \mathrm{C}, 10$ saat & & $6.49^{\mathrm{a}}$ & $37.52^{c}$ & $83.35^{c}$ \\
\hline $60^{\circ} \mathrm{C}$, 9 saat & _ Vakumlu & $6.05^{a}$ & $41.04^{a}$ & $91.22^{\mathrm{a}}$ \\
\hline $70^{\circ} \mathrm{C}, 8$ saat & kurutucu & $6.06^{a}$ & $39.86^{b}$ & $89.48^{b}$ \\
\hline
\end{tabular}

*Aynı satırda farklı harfleri taşıyan ortalamalar arası fark önemlidir $(p<0.05)$. Tüm değerler 3 tekerrürün ortalamasıdır. 
Kurutma işleminin avokadoların duyusal özellikleri üzerine etkisi

Duyusal analiz sonuçları incelendiğinde vakumla kurutulmuş örneklerin genel olarak akışkan yatak kurutucu ile kurutulmuş örneklerden daha yüksek puanlar aldığı görülmektedir (Çizelge 5). Sıcaklık yükseldikçe hem akışkan yatak kurutucu ile kurutulmuş avokadoların hem de vakumlu kurutucu ile kurutulmuş avokadoların duyusal panelden aldığı puanlarda düşüş görülmüştür. Diğer taraftan çok düşük sıcaklıklarda kurutulmuş örnekler de duyusal panelden daha düşük puanlar almıştır. Çok düşük sıcaklıklarda alınan puanların düşmesinin nedeni uzayan kuruma süresi ile açıklanabilir.

Çizelge 5. Kurutulmuş avokado dilimlerinin duyusal özellikleri Kurutma sıcaklığı $\left({ }^{\circ} \mathrm{C}\right) /$

\begin{tabular}{|c|c|c|c|c|c|}
\hline Zaman (saat) & & Görünüş & Doku & Lezzet & Genel İzlenim \\
\hline $50^{\circ} \mathrm{C}, 8$ saat & & $4.6^{\mathrm{a}}$ & $3.8^{b}$ & $4.5^{b}$ & $4.6^{b, c}$ \\
\hline $60^{\circ} \mathrm{C}, 7$ saat & - Akışkan yatak & $4.8^{\mathrm{a}}$ & $3.4^{c}$ & $4.2^{b, c}$ & $4.7^{b}$ \\
\hline $70^{\circ} \mathrm{C}, 6$ saat & kurutucu & $4.2^{b}$ & $3.2^{c}$ & $4.0^{c}$ & $4.1^{d}$ \\
\hline $50{ }^{\circ} \mathrm{C}, 10$ saat & & $4.7^{\mathrm{a}}$ & $4.4^{\mathrm{a}}$ & $4.6^{b}$ & $4.7^{b}$ \\
\hline $60^{\circ} \mathrm{C}$, 9 saat & Vakumlu & $4.9^{a}$ & $4.2^{\mathrm{a}}$ & $4.8^{\mathrm{a}}$ & $4.9^{a}$ \\
\hline $70^{\circ} \mathrm{C}, \quad 8$ saat & kurutucu & $4.2^{b}$ & $3.5^{b}$ & $4.2^{b}$ & $4.5^{c}$ \\
\hline
\end{tabular}

\footnotetext{
*Aynı satırda farklı harfleri taşıyan ortalamalar arası fark önemlidir $(p<0.05)$. Tüm değerler 3 tekerrürün ortalamasıdır.
}

\section{Sonuç ve Öneriler}

Kurutulmuş meyveler günümüzde atıştırmalıklarla beslenme kültürünün giderek yaygınlaştığı dönemde sağlıklı atıştırmalıkların elde edilmesinde önemli bir yere sahiptir. Bu çalışmada, avokado meyvesinin kurutulması deneylerinde kurutucu türünün ve kurutma sıcaklığı ile süresinin kurutulmuş ürünün kalite karakteristikleri üzerine etkileri incelenmiştir. Kurutma işlemi sonucunda elde edilen ürünün fiziksel, kimyasal ve duyusal açıdan en iyi kalitede elde edilmesi için ürüne uygun kurutma işlemi ve koşullarının seçilmesinin son derece önemli olduğu ortaya çıkarılmıştır. Vakum kurutma işlemi avokadoların kalite karakteristiklerini daha iyi korumasına rağmen kurutma süresi uzadığında ürünün özellikle duyusal kalitesinde olumsuz etkilere sebep olmuştur. Duyusal analiz sonuçları, avokadoların içerdiği yüksek orandaki yağ nedeniyle akışkan yataklı kurutucu ile kurutma esnasında oluşan ransid lezzetin vakumla kurutma işlemiyle önemli ölçüde engellendiğini ortaya çıkarmıştır. Bu nedenle, bu çalışmada avokadoların kurutulmasında vakumlu kurutmanın diğer yöntemlerle kombine olarak kullanılmasının ya da son işlem olarak kullanılmasının daha uygun olacağı ortaya çıkarılmıştır.
Çıkar Çatışması Beyanı: Makale yazarları aralarında herhangi bir çıkar çatışması olmadığını beyan ederler.

Araştırmacıların Katkı Oranı Beyan Özeti: Yazarlar makaleye eşit oranda katkı sağlamış olduklarını beyan ederler.

\section{Kaynaklar}

Alibas, I. 2009. Microwave, vacuum, and air drying characteristics of collard leaves. Drying Technology, 27(11), 1266-1273.

AOAC. 2005. Official methods of analysis (18th ed.). Arlington, VA: Association of Official Analytical Chemists.

Artnaseaw, A., Theerakulpisut, S., Benjapiyaporn, C. 2010. Drying characteristics of Shiitake mushroom and Jinda chili during vacuum heat pump drying. Food and Bioproducts Processing, 88(2-3), 105-114.

Asami, D. K, Hong, Y. J, Barrett, D. M, Mitchell, A. E. 2003. Comparison of the total phenolic and ascorbic acid content of freeze-dried and air-dried marionberry, strawberry, and corn grown using conventional, organic, and sustainable agricultural practices. Journal of 
agricultural and food chemistry, 51(5), 1237-1241.

Astudillo-Ordóñez, C. E, Rodríguez, P. 2018. Physicochemical parameters of avocado Persea americana Mill. cv. Hass (Lauraceae) grown in Antioquia (Colombia) for export. Corpoica Ciencia y Tecnología Agropecuaria, 19(2), 383-392.

Balzarini, M. F., Reinheimer, M. A., Ciappini, M. C., \& Scenna, N. J. 2018. Comparative study of hot air and vacuum drying on the drying kinetics and physicochemical properties of chicory roots. Journal of food science and technology, 55(10), 4067-4078.

Bchir, B., Besbes, S., Karoui, R., Paquot, M., Attia, H., \& Blecker, C. 2012. Osmotic dehydration kinetics of pomegranate seeds using date juice as an immersion solution base. Food and Bioprocess Technology, 5(3), 999-1009.

Bolek, S., \& Ozdemir, M. 2017. Optimization of roasting conditions of Pistacia terebinthus in a fluidized bed roaster. LWT, 80, 67-75.

Cemeroğlu, B. 2010. Gıda Analizleri, Gıda Teknolojisi Yayınları Derneği Yayınları, No:39, 2. Baskı Ankara.

Chang, C. H, Lin, H. Y, Chang, C. Y, Liu, Y. C. 2006. Comparisons on the antioxidant properties of fresh, freeze-dried and hot-air-dried tomatoes. Journal of Food Engineering, 77(3), 478-485.

Chartzoulakis, K., Patakas, A., Kofidis, G., Bosabalidis, A., Nastou, A. 2002. Water stress affects leaf anatomy, gas exchange, water relations and growth of two avocado cultivars. Scientia horticulturae, 95(1-2), 3950.

Dinani, S. T., Hamdami, N., Shahedi, M., Havet. M., 2015. Quality assessment of mushroom slices dried by hot air combined with an electrohydrodynamic (EHD) drying system. Food and Bioproducts Processing, 94, 572580.

Gabas, A. L., Telis V. R. N., Sobral, P. J. A., TelisRomero J. 2007. Effect of maltodextrin and arabic gum in water vapor sorption thermodynamic properties of vacuum dried pineapple pulp powder. Journal of Food Engineering, 82(2), 246-252.

Gallagher, E., Gormley, T.R., Arendt, E.K., 2003. Crust and crumb characteristics of gluten free breads. Journal of Food Engineering 56(2): 153-161

Gürlek, G., Akdemir, Ö., Güngör, A. 2015. Gıda Kurutulmasında Isı Pompalı Kurutucuların Kullanımı Ve Elma Kurutmada Uygulanması. Pamukkale University Journal of Engineering Sciences, 21(9).
International Organization for Standardization (ISO) 8586. 2012. Sensory Analysis- General guidelines for the selection, training and monitoring of selected assessors and expert sensory assessors.

Krokida, M. K., Maroulis, Z. B., Saravacos, G. D. 2001. The effect of the method of drying on the colour of dehydrated products. International journal of food science \& technology, 36(1), 53-59.

Litvin, S., Mannheim, C. H., \& Miltz, J. 1998. Dehydration of carrots by a combination of freeze drying, microwave heating and air or vacuum drying. Journal of food engineering, 36(1), 103-111.

Martynenko, A., Zheng, W. 2016. Electrohydrodynamic drying of apple slices: Energy and quality aspects. Journal of Food Engineering, 168, 215-222.

Mayor, L., Cunha, R. L., Sereno, A. M. 2007. Relation between mechanical properties and structural changes during osmotic dehydration of pumpkin. Food Research International, 40(4), 448-460.

Meilgaard, M. C., Civille, G. V., \& Carr, B. T. 2016. Sensory evaluation techniques (5th ed., pp. 123-152). Boca Raton: CRC Press.

Michalczyk, M., Macura, R., Matuszak, I. 2009. The effect of air-drying, freeze-drying and storage on the quality and antioxidant activity of some selected berries. Journal of Food Processing and Preservation, 33(1), 11-21.

Opalić, M., Domitran, Z., Komes, D., Belščak, A., Horžić, D., \& Karlović, D. 2009. The effect of ultrasound pre-treatment and air-drying on the quality of dried apples. Journal of Food Science, 27(SI), S297-S300.

Piga A, Pinna I, Özer K. B, Agabbio M, Aksoy U. 2004. Hot air dehydration of figs (Ficus carica L.): drying kinetics and quality loss. International journal of food science \& technology, 39(7), 793-799.

Rodríguez-Carpena, J. G., Morcuende, D., Andrade, M. J., Kylli, P., \& Estévez, M. 2011. Avocado (Persea americana Mill.) phenolics, in vitro antioxidant and antimicrobial activities, and inhibition of lipid and protein oxidation in porcine patties. Journal of agricultural and food chemistry, 59(10), 5625-5635.

Shi, Q., Zheng, Y., \& Zhao, Y. 2013. Mathematical modeling on thin-layer heat pump drying of yacon (Smallanthus sonchifolius) slices. Energy Conversion and Management, 71, 208-216.

Shishehgarha, F., Makhlouf, J., Ratti, C. 2002. Freeze-drying characteristics of 
strawberries. Drying technology, 20(1), 131145.

Shofian, N. M., Hamid, A. A., Osman, A., Saari, N., Anwar, F., Pak, Dek M. S., Hairuddin, M. R. 2011. Effect of freeze-drying on the antioxidant compounds and antioxidant activity of selected tropical fruits. International Journal of molecular sciences, 12(7), 4678-4692.

Teles, U. M., Fernandes, F. A., Rodrigues, S., Lima, A. S., Maia, G. A, Figueiredo, R. W. 2006. Optimization of osmotic dehydration of melons followed by air-drying. International journal of food science \& technology, 41(6), 674-680.

Tsami, E., \& Katsioti, M. 2000. Drying kinetics for some fruits: Predicting of porosity and color during dehydration. Drying Technology, 18(7), 1559-1581.

Wong, D. S., Lai, F. C. 2004. EHD-enhanced drying with auxiliary heating from below. Journal of energy resources technology, 126(2), 133-139.

Ye, XY., Wang, HX., Liu, F., Ng, T.B. 2000. Ribonuclease, cell-free translation-inhibitory and superoxide radical scavenging activities of the iron-binding protein lactoferrin from bovine milk. The international journal of biochemistry \& cell biology, 32(2), 235-241.

Yıldız, Z., Gökayaz, L. 2019. Güneş Enerjili Kurutucuda Kurutulan Elma Dilimlerinin Kurutma Koşullarının RSM ile Optimizasyonu. Çukurova Tarım ve Gıda Bilimleri Dergisi, 34(2), 100-108.

Yongsawatdigul, J., Gunasekaran, S. 1996. Microwave-vacuum drying of cranberries: Part II. Quality evaluation. Journal of Food Processing and Preservation, 20(2), 145156.Akcura, M., Kaya, Y., Taner, S., Ayranci, R. 2006. Parametric stability analyses for grain yield of durum wheat. Plant Soil and Environment, 52 (6), 254. 